\title{
МЕДИКО-ЕКСПЕРТНІ КРИТЕРІЇ ОБМЕЖЕННЯ ЖИТТЄДІЯЛЬНОСТІ ПРИ НАСЛІДКАХ ПЕРЕНЕСЕНОГО ІНСУЛЬТУ
}

${ }^{1}$ Київський міжнародний медичний університет, м. Київ, Україна

${ }^{2}$ Броварська центральна районна лікарня, м. Бровари, Україна

\begin{abstract}
Мета: адаптувати Міжнародну класифрікацію фрункціонування, обмеження життєдіяльності та здоров'я (МКФ) для використання при обстеженні хворих із наслідками перенесеного інсульту.

Матеріали і методи. У ангіоневрологічному відділенні Броварської центральної лікарні проведено дослідження 110 хворих працездатного віку із наслідками перенесеного інсульту. Всі хворі пройшли стандартне клінічне неврологічне обстеження і тестування за МКФ.

Результати. Визначено чинники, розроблено критерії обмеження життєдіяльності у головних ссрерах життя. Доведено, що адаптація МКФ дозволяє застосовувати ії при експертній діагностиці, фрормулюванні правильного клінічного, фуннкціонального діагнозу, дає можливість оцінити потенціал і ефективність реабілітаційних заходів у хворих із наслідками перенесеного інсульту.

Висновки. 1. Застосування МКФ дає змогу об'єктивно оцінити стан хворих, реабілітаційний потенціал і есрективність проведення реабілітаційних заходів у хворих із наслідками перенесеного інсульту.

2. Використання розроблених нами критеріїв обмеження життєдіяльності дозволить підвищити якість медикосоціальної експертизи хворих, які перенесли інсульт, а подальші дослідження оптимізувати нові підходи до реабілітації цієї категорії хворих та адаптації в суспільстві.
\end{abstract}

КЛЮЧОВІ СЛОВА: наслідки перенесеного інсульту; діагноз; медико-соціальна експертиза; обмеження життєдіяльності; Міжнародна класифікація функціонування.

Цереброваскулярна патологія $€$ однією із найскладніших і невирішених проблем охорони здоров'я, має велике соціально-економічне значення через поширення та тяжкість медичних й соціальних наслідків для суспільства. Інсульт - небезпечне гостре захворювання, яке $є$ другою причиною смертності населення в Україні, серед чоловіків показник становить 606, а серед жінок - 408 випадків на 100 тис. населення. Це у декілька разів більше, ніж в інших країнах Європи [1]. За даними ООН, у світі кожний десятий житель планети - інвалід. До поняття «реабілітація інвалідів» входять: відновлення або компенсація того, що не можна відновити, пристосування до життя і залучення до трудового процесу хворого або інваліда [3, 5]. За даними різних дослідників, летальність в гострий період становить 15-20\%, ще близько 20 \% помирають протягом року. Чверть пацієнтів, які вижили, потребує постійного стороннього нагляду, допомоги і лише 20-25\% осіб, які перенесли ішемічний інсульт, повертаються до праці $[2,14]$. Віддалені результати лікування ішемічного інсульту прямо залежать від адекватності організаційних та лікувально-профрілактичних заходів $[1,17]$. Враховуючи, що найбільш вивченими 3 всіх наслідків інсульту $є$ рухові розлади, які у вигляді парезів трапляються у 80-90 \% осіб, які перенесли інфаркт головного мозку. Вони часто поєднуються 3 мовними розладами, порушеннями

(с) М.М. Матяш, О.П. Онопрієнко, 2018 координації та чутливості [16]. Не секрет, що значно менше уваги приділяють іншим наслідкам: депресії після інсульту, когнітивним, емоційно-вольовим розладам, професійній та соціальній дезадаптації $[12,18]$. Незважаючи на численні дослідження, присвячені ЦВЗ, донині лікарі стикаються з труднощами при діагностиці, оцінці тяжкості, фрормулюванні етіологічного, функціонального діагнозу, лікуванні, реабілітації, медико-соціальній експертизі інсультів як у гострий, так і віддалений періоди, прогнозам $[2,11]$. На відміну від МКХ-10, про існування МКФ навіть не підозрює переважна кількість українських невропатологів, але вона $є$ азбукою реабілітації незалежно від профрілю, обмеження життєдіяльності та здоров'я, забезпечує покрокове планування процесу реабілітації з урахуванням потреб пацієнта, фрактичних його порушень і можливостей їх регресу, аспектів оточуючого середовища [1].

Мета дослідження: адаптувати Міжнародну класифрікацію функціонування, обмеження життєдіяльності і здоров'я для використання при обстеженні хворих із наслідками перенесеного інсульту.

Матеріали і методи. У ангіоневрологічному відділенні Броварської центральної лікарні обстежено 110 хворих працездатного віку із наслідками перенесеного інсульту. Діагноз верифіковували за допомогою спіральної комп'ютерної томографії або магнітно-резонансної томографрії головного мозку. Для оцінки неврологічного 
дефіциту у віддалений період інсульту використовували стандартні неврологічні клінічні обстеження.
Результати дослідження та їх обговорення. Для оцінки клінічно вираженого неврологічного дефріциту ми виділяли об'єктивні симптоми (табл. 1).

Таблиця 1. Клініко-неврологічна об'єктивна симптоматика обстежених хворих

\begin{tabular}{|l|c|c|}
\hline \multicolumn{1}{|c|}{ Ознака } & \multicolumn{2}{c|}{ Поширення в групі } \\
\cline { 2 - 3 }$(\mathrm{n}=110)$
\end{tabular}

Клінічна картина хвороби включає класичні неврологічні синдроми, зумовлені відповідними патоморфологічними змінами речовини головного мозку. Вплив на життєдіяльність хворих визначають клінічні синдроми інсульту, та коморбідних до нього станів, що призводять до їх дезадаптації: 1) синдроми неврологічного десріциту; 2) синдроми психічних розладів; 3) синдром вегетативної дисорункції; 4) епілептичний синдром $[12,13]$.

Синдром дефріциту (параліч і парез, екстрапірамідні та мозочкові розлади, порушення фрункції черепних нервів тощо) виникає у гострий період інсульту, іноді середньої тяжкості інсульту, в проміжний період має тенденцію до регресування.

Синдром психічних дисфункцій (неврозоподібний, психопатоподібний, психоорганічний) може виникати внаслідок інсульту будь-якої тяжкості та в різні періоди його перебігу. При визначенні їх характеру в хворих значну увагу варто приділяти преморбідним фракторам (неврози, акцентуація особистості, наявність нейро- та психотравми до інсульту), які зумовлюють виражений та торпідний характер перебігу вказаних ускладнень.

Синдром вегетативної дисфункції може клінічно визначатися вегетативно-судинним, вегетативно-вісцеральним, обмінно-ендокринним синдромами (коливання артеріального тиску, порушення серцевого ритму, вегетативний криз, синкопальні стани, порушення терморегуляції, водно-електролітного, жирового обміну).

У результаті дослідження 110 хворих із віддаленими наслідками інсульту і проведеної раніше медичної реабілітації у 64 (57,1 \%) хворих зареєстровано помірне обмеження життєдіяльності, у 46 (41,1 \%) - виражене, у 2 (1,8 \%) - різко виражене. Дані свідчать про ефективність проведення реабілітаційних заходів і можливості відбору хворих для подальшої реабілітації за визначенням індивідуального реабілітаційного потенціалу. Значна частота, тяжкість, відмінності перебігу і наслідків інсульту вимагають удосконалення класифрікації. Вона повинна бути комплексною (багатоплановою), враховувати можливість діагностики у віддалений період прямих наслідків хвороби і патогенетично пов'язаних із нею синдромів, а також основні варіанти перебігу цереброваскулярної хвороби головного мозку. Запропонована класифрікація МКФ [4] включає чотири розділи, що доповнюють один одного, тому багато клінічних фрорм інсульту наведено в декількох її розділах.

І. За патогенетичними особливостями виникнення (розвитку):

1. Переважно прямі наслідки: геміпарез, афазія, геміанопсія, вестибулопатія, астенічний синдром тощо; поєднані.

2. Переважно непрямі (опосередковані) наслідки: синдром вегетативної дистонії, артеріальна гіпертензія, ранній церебральний атеросклероз, нейроендокринний синдром, нормотензивна поєднана гідроцефралія, пізні форми післяопераційної епілепсії, психоорганічний синдром тощо; поєднані.

II. За клінічними фрормами залежно від превалюючих морфологічних змін: 
1. Тканинні: атрофрія мозку (локальна і дифузна), післяінсультна, післяопераційна внутрішньомозкова кіста, оболонково-мозкові рубці, ураження черепно-мозкових нервів, післяопераційні дефекти черепа; поєднані.

2. Лікворні: післяінсультна, післяопераційна гідроцефалія, хронічна гігрома, субарахноїдальна кіста, пневмоцефалія; поєднані.

3. Судинні: аневризма та ішемія, тромбоз синусів, каротидно-кавернозне співустя; поєднані.

III. За основним (провідним) синдромом:

1. Вегетативно-дистонічний.

2. Судинний.

3. Ліквородинамічний.

4. Церебрально-вогнищевий.

5. Післяопераційна епілепсія.

6. Післяінсультна нарколепсія.

7. Вестибулярний.

8. Нейроендокринний.

9. Астенічний.

10. Психоорганічний.

IV. За особливостями перебігу:

1. Переважно непрогресуючі: субарахноїдальна і внутрішньомозкова лікворна кіста, оболонково-мозкові рубці після видалення внутрішньочерепної гематоми, церебральновогнищевий синдром, ураження черепних нервів тощо; поєднані.

2. Переважно прогресуючі: атрофрія мозку, гідроцефалія 3 порушеннями ліквородинаміки, нейроендокринний синдром, синдром вегетативної дистонії, артеріальна гіпертензія чи гіпотензія, ранній церебральний атеросклероз, психоорганічний синдром тощо; поєднані.

Перший розділ класифікації виділений у зв'язку із суттєвими патогенетичними особливостями формування численних наслідків інсульту. У другому розділі описано морфологічні наслідки інсульту, наведені згідно з класифікацією Інституту нейрохірургії ім. М. М. Бурденка [17]. У третьому розділі перераховані основні клінічні синдроми, що обмежують життєдіяльність і працездатність хворих. Четвертий розділ, що відображає динаміку наслідків інсульту, дозволяє краще оцінити прогноз, реабілітаційний потенціал, вирішити питання консервативного лікування хворих. Причинний зв'язок цих процесів з отриманим інсультом може бути встановлений 3 урахуванням преморбідної соматичної патології та потребує обов'язкової параклінічної верифрікації з використанням найінформативніших сучасних діагностичних методів (комп'ютерна та магнітно-резонансна томографрія 3 адекватним трактуванням отриманої візуальної інформації - врахування спадкових, перинатальних і вікових патоморфологічних змін мозку, адекватна оцінка технічних можливостей використаної апаратури, ультразвукова доплерографія церебральних судин, відповідна лабораторна діагностика у разі підозри на інорекційно-алергічний характер уражень). Класифікацію доцільно використовувати при вирішенні завдань медико-соціальної експертизи, розробці індивідуальної програми реабілітації. Первинна експертно-реабілітаційна діагностика ґрунтується на визначенні ступеня обмеження різних видів життєдіяльності. Нині методологічною базою для цієї діяльності в Україні $€$ «Інструкція по встановленню груп інвалідності» (наказ від 07.04.2004 р. № 183 МО3 України). Разом із тим, вона орієнтується на прийняту ВООЗ Міжнародну класиорікацію порушень, обмежень життєдіяльності та соціальної недостатності (1980р.) і Міжнародну класифрікацію функціонування, обмеження життєдіяльності та здоров'я (2001р.) [4].

У разі професійного захворювання або каліцтва перероблено та доповнено наказ від 05.08.1998 р. № 238 МО3 України «Критерії встановлення ступеня стійкої втрати професійної працездатності у відсотках, особливостей працевлаштування хворих та інвалідів», що регламентує відсоткові характеристики стійкої втрати професійної працездатності постраждалого [6].

Дуже важливо розцінювати проблему наслідку перенесеного інсульту не виключно як медичну, але, по суті, вона має державні, соціальні й екологічні аспекти. Більшість пацієнтів після інсульту не забезпечена належним соціальним захистом, можливістю отримання достатньо ефективної реабілітації. Діяльність медичних закладів і соціальних служб не поєднана загальною стратегією та мультидисциплінарним підходом. Соціальні працівники беруть участь у наданні допомоги хворому лише на етапі його перебування вдома і переважно у випадках, коли в пацієнта немає рідних і близьких [8]. Завданням невропатологів, окрім пріоритету забезпечення алгоритму поетапного надання спеціалізованої допомоги хворому з інсультом, є правильне офрормлення медичної документації, а найголовніше, згідно з МKX-10 та МКФ, правильне фрормулювання клінічного діагнозу враховуючи періоди, типи інсультів, локалізацію ураження артеріального басейну, топічну характеристику, ступені тяжкості неврологічної симптоматики, здатність до самообслуговування, спілкування, перенавчання, трудової діяльності, що є критерієм подальшої реабілітації та прогностичного предиктора на якість життя, профілактику повторних епізодів [13, 18].

Обмеження життєдіяльності - неспроможність до повсякденної діяльності способом та в обсязі, звичних для людини, що створює перешкоди в оточуючому середовищі людини - вона потрапляє в незручне становище, порівняно зі здоровими, а це призводить до соціальної недостатності, часткова або повна втрата здатності до самообслуговування, пересування, орієнтації, 
спілкування, навчання, контролю за поведінкою, а також значне обмеження обсягу трудової діяльності, зниження кваліфікації.

Категорії (критерії) життєдіяльності - це здатність до самообслуговування, пересування, орієнтації, контролю за власною поведінкою, спілкування, навчання, виконання трудової діяльності:

- здатність до пересування - ефективне пересування у своєму оточенні (ходити, бігати, долати перешкоди, користуватися особистим та громадським транспортом). Параметри оцінки характер ходи, темп пересування, відстань, яку долає хворий, здатність самостійно користуватися транспортом, потреба у допомозі інших осіб під час пересування;

- здатність до самообслуговування - ерективне виконання повсякденної побутової діяльності й задоволення потреб без допомоги інших осіб. Параметри оцінки - інтервал часу, через який виникає потреба в допомозі: епізодична допомога (менше одного разу на місяць), регулярна (декілька разів на місяць), постійна допомога (декілька разів на тиждень - регульована або декілька разів на день - нерегульована допомога);

- здатність до орієнтації - самостійна орієнтація у просторі та часі, уявлення про навколишні предмети. Основні системи орієнтації - зір та слух. Здатність до орієнтації в цьому випадку оцінюють за умови нормального стану психічної діяльності та мови. Параметри оцінки - здатність розрізняти зорові образи людей та предметів на відстані, що збільшується, та в різних умовах (наявність або відсутність перешкод, знайомство 3 обстановкою); здатність розрізняти звуки та усну мову (слухова орієнтація) за відсутності або наявності перешкод і ступінь компенсації порушення слухового сприйняття усної мови іншими способами (письмо, невербальні форми); необхідність використання технічних засобів для орієнтації та допомоги інших осіб у різних видах повсякденної діяльності (у побуті, навчанні, на виробництві);

- здатність до спілкування (комунікативна здатність) - встановлення контактів 3 іншими людьми та підтримка суспільних взаємозв'язків (порушення спілкування, пов'язані 3 розладом психічної діяльності, в цьому випадку не розглядають). Основним засобом комунікації є усне мовлення, допоміжним - читання, письмо, невербальна мова (жестів, знаків). Параметри оцінки - характеристика кола осіб, з якими можлива підтримка контактів, а також потреба в допомозі інших осіб у процесі навчання й трудової діяльності;

- здатність контролювати свою поведінку поводитися відповідно до морально-етичних і правових норм суспільства. Параметри оцінки здатність ідентифікувати себе і дотримуватися установлених суспільних норм, ідентифікувати людей та об'єкти і розуміти стосунки між ними, правильно сприймати, інтерпретувати й адекватно реагувати на традиційну та незвичну ситуацію, дотримуватися особистої безпеки та охайності;

- здатність до навчання - сприймання, засвоєння та накопичування знань, формування навичок і умінь (побутові, культурні, профресійні тощо) у цілеспрямованому процесі навчання; здатність до професійного навчання - оволодіння теоретичними знаннями та практичними навичками й умінням конкретної профресії. Параметри оцінки - можливість навчання у звичайних або спеціально створених умовах (спеціальний навчальний заклад або група, навчання в домашніх умовах тощо); обсяг програми, термін і режим навчання; можливість освоєння профресій різного кваліфікаційного рівня або тільки деяких видів роботи; необхідність використання спеціальних засобів навчання і залучення допомоги інших (крім викладача) осіб;

- здатність до трудової діяльності - сукупність фрізичних та духовних можливостей людини, яка визначається станом здоров'я, що дозволяє їй займатися різного роду трудовою діяльністю. Профресійна працездатність - здатність людини якісно виконувати роботу, передбачену конкретною професією, що дозволяє реалізувати трудову зайнятість у певній сорері виробництва згідно 3 вимогами до змісту й обсягу виробничого навантаження, установленого режиму роботи та умов виробничого середовища. Параметри оцінки збереження або втрата профресійної здатності, можливість трудової діяльності в іншій професії, за кваліфікацією рівнозначній попередній, оцінка допустимого обсягу роботи у своїй професії та на посаді, можливість трудової зайнятості в звичайних або спеціально створених умовах. Порушення профресійної працездатності - найчастіша причина соціальної недостатності - може виникати первинно, якщо інші категорії життєдіяльності не порушені, або вторинно через обмеження життєдіяльності. Здатність до праці в конкретній професії інвалідів з обмеженням інших сторін життєдіяльності може бути збережена повністю або частково, або відновлена засобами професійної реабілітації, після чого інвалід може працювати у звичайних або спеціально створених умовах із повною або неповною тривалістю робочого дня.

Ступінь обмеження життєдіяльності - величина відхилення від норми діяльності людини внаслідок порушення здоров'я. Ступінь обмеження життєдіяльності характеризується однією або поєднанням декількох зазначених найважливіших її ознак. Виділяють три ступеня: помірно виражений, виражений, різкий.

І. Помірно виражене обмеження життєдіяльності зумовлене помірними порушеннями фрункцій органів та систем організму і призводить до помірного обмеження можливості навчання, спілкування, 
орієнтації, контролю за своєю поведінкою, пересування, самообслуговування, участі у трудовій діяльності.

II. Виражене обмеження життєдіяльності зумовлене вираженим порушенням фрункцій органів та систем організму і полягає у значному порушенні можливості навчання, спілкування, орієнтації, контролю за своєю поведінкою, пересування, самообслуговування, участі у трудовій діяльності.

III. Різке обмеження життєдіяльності виникає внаслідок різких порушень фрункцій органів чи систем організму, що призводить до неможливості або різкого порушення здатності чи можливості навчання, спілкування, орієнтації, контролю за своєю поведінкою, пересування, самообслуговування, участі у трудовій діяльності та супроводжується необхідністю в сторонньому догляді (стороння допомога).

З урахуванням вищезазначених позицій розроблені критерії встановлення груп інвалідності.

Перша група - нездатність до самообслуговування або повна залежність від інших осіб; нездатність до самостійного пересування та повна залежність від інших осіб; нездатність до орієнтації (дезорієнтація); нездатність до спілкування; нездатність контролювати свою поведінку.

Друга група - здатність до самообслуговування $з$ використанням допоміжних засобів та/або за допомогою інших осіб; здатність до самостійного пересування 3 використанням допоміжних засобів та/або за допомогою інших осіб; нездатність до трудової діяльності чи здатність до виконання трудової діяльності у спеціально пристосованих умовах із використанням допоміжних засобів та/або спеціально обладнаного робочого місця за допомогою інших осіб; нездатність до навчання чи здатність до навчання тільки у спеціальних навчальних закладах чи за спеціальними програмами вдома; здатність орієнтації у часі та просторі, що потребує допомоги інших осіб; здатність до спілкування з використанням допоміжних засобів та/або за допомогою інших осіб; здатність частково або повністю контролювати свою поведінку тільки за допомогою сторонніх осіб.

Третя група - здатність до самообслуговування з використанням допоміжних засобів; здатність до самостійного пересування при більш тривалій витраті часу; здатність до навчання в навчальних закладах загального типу при дотриманні спеціального режиму навчального процесу та/або 3 використанням допоміжних засобів за допомогою інших осіб (крім персоналу, який проводить навчання); здатність до трудової діяльності за умови зниження кваліфрікації чи зменшення обсягу виробничої діяльності, неможливості виконання роботи за фрахом; здатність до орієнтації у часі та просторі за умови використання допоміжних засобів; здатність до спілкування, що характеризується зниженням швидкості, зменшенням обсягу засвоєння, отримання і передачі інформації.

При оцінці стану життєдіяльності хворих після перенесеного інсульту варто враховувати типи інсульту: ГІ (геморагічний інсульт), ГІ 3 фрормуванням медіальної внутрішньомозкової чи латеральної внутрішньомозкової гематоми, II (ішемічний інсульт), АТІ (атеротромботичний інсульт), KEI (кардіоемболічний інсульт), тяжкість інсульту, ефективність проведеного лікування в гострий, проміжний і віддалений періоди хвороби, перебіг, тяжкість дефріцитарних, психічних, ліквородинамічних, вегетативно-судинних та епілептичних синдромів, а також дати змогу змінити критерії в процесі реабілітації з метою зменшення фрункціональних порушень, що вплинуть на якість життя інваліда [2, 12].

Крім того, обов'язково враховують комплекс соціальних фракторів. Вирішального значення при проведенні медико-соціальної експертизи надають тяжкості дефріцитарних та психопатологічних синдромів та їх поєднанням. Варто відзначити, що при визначенні стану життєдіяльності постраждалих враховують домінуючі синдроми захворювання. Легкі функціональні порушення або практичне одужання хворих не обмежують їхньої життєдіяльності, тому інвалідами їх не визнають. У тих самих випадках, при яких після перенесеного інсульту залишаються фрункціональні порушення, що впливають на стан життєдіяльності хворих, виникає потреба у визнанні їх інвалідами або встановлюють відповідні обмеження навантажень на роботі, скорочення робочого часу.

При винесенні експертних рішень враховують як медичні, так і соціальні критерії: професійний маршрут, санітарно-гігієнічні умови праці на колишній і новій роботі, ефективність профрілактичних заходів, кваліфрікацію та заробітну платню до і після перенесеного інсульту, вік і освіту постраждалого, можливості для перекваліфрікації та перенавчання на робочому місці, спеціальних курсах, у навчальних комбінатах, а також у вищих і середніх навчальних закладах країни, можливості для раціонального працевлаштування і фрактичне працевлаштування. У разі легких віддалених наслідків інсульту та при поєднанні травмування на виробництві, в результаті яких $є$ незначні зміни обсягу і якості виконуваної роботи, визначають іноді й відсотки втрати професійної працездатності від 5 до $25 \%$.

Третю групу інвалідності встановлюють хворим з такими обмеженнями життєдіяльності, що призводять до значного зниження можливостей соціальної адаптації при зниженні кваліфікації: значне зниження можливостей трудової діяльності, в тому числі зменшення обсягу виконуваної роботи; помірний вегетативно-судинний синдром 
середньої частоти з тяжкими вегетативними пароксизмами; помірний нейроендокринно-обмінний синдром та нейротрофрічні фрорми гіпоталамічного синдрому; помірні, а в деяких випадках легкі рухові, мовні (лектор, викладач, артист тощо), координаторні, вестибулярні (водій, монтажник на висоті тощо) порушення; помірний геміпарез; поєднання (помірних) епілептиорормного та вестибулярного синдромів; поєднання помірних вестибулярного синдрому та вегетативної дисфункції пароксизмального перебігу (з легкими або середньої тяжкості кризами до 4-5 на місяць); психоорганічний синдром із помірним, а в деяких випадках (вчений, викладач, лектор тощо) незначним зниженням інтелекту.

Третю групу інвалідності встановлюють хворим, які перенесли легкий інсульт та в яких у проміжний і віддалений періоди мають місце помірні та виражені фрункціональні порушення, що призводять до вираженого обмеження життєдіяльності та необхідності в соціальній допомозі та захисті. Хворим із третьою групою інвалідності залежно від тяжкості клінічних фрорм і синдромів дають дозвіл на легку працю з обмеженням фрізичного, психоемоційного навантаження.

Другу групу інвалідності встановлюють при різко вираженому обмеженні життєдіяльності, яке проявляється у вираженій соціальній дезадаптації за можливості самообслуговування: помірний тетрапарез; виражена атаксія, виражений геміпарез; виражений гіпоталамічний синдром; поєднання 3 кірково-вогнищевою симптоматикою або з частими тяжкими і середньої тяжкості вазовегетативними пароксизмами чи 3 вираженими вестибулярними розладами, що не піддаються лікуванню; виражений психоорганічний синдром із значним зниженням інтелекту; виражений екстрапірамідний синдром.

Другу групу інвалідності найчастіше встановлюють хворим, які перенесли тяжкий ішемічний чи геморагічний інсульт із такими формами: психічні або вегетативні дисорункції, паркінсонізм та інші, що призводять до значного обмеження життєдіяльності та соціальної дезадаптації, необхідності у соціальній допомозі та захисті, однак ще зберігається здатність до самообслуговування.
Першу групу інвалідності встановлюють при стійких надто тяжких фрункціональних порушеннях, що призводять до різкого обмеження життєдіяльності та соціальної дезадаптації, коли хворі потребують постійного догляду або допомоги, а саме за умови геміплегії; при вираженому судинному синдромі паркінсонізму; вираженій атаксії; вираженому гіперкінетичному синдромі з неможливістю стояння та ходи, а також виконання будьяких необхідних рухів для самообслуговування; тотальній афазії з неможливістю спілкування; вираженому тетрапарезі; післяопераційній (внаслідок видалення інсульт-гематоми) епілепсії з частими генералізованими судомами чи поліморфними нападами (12 разів і більше на місяць) із схильністю до серійних нападів та епілептичних статусів, довготривалими сутінковими розладами свідомості; психоорганічному синдромі з недоумством.

Першу групу інвалідності, як правило, встановлюють хворим, які перенесли інсульт тяжкого ступеня. Такі хворі прикуті до ліжка, мають грубі геміта тетрапарези, порушення мови (сенсомоторна афразія, алексія), амавроз, виражену атаксію, психоорганічний синдром, потребують постійного стороннього догляду та допомоги $[7,11,12]$.

\section{Висновки}

1. Застосування МКФ дає змогу об'єктивно оцінити стан хворих, реабілітаційний потенціал і ефективність проведення реабілітаційних заходів у хворих із наслідками перенесеного інсульту.

2. Використання розроблених нами критеріїв обмеження життєдіяльності при наслідках перенесеного інсульту дозволить підвищити якість медико-соціальної експертизи хворих, які перенесли інсульт.

Перспективи подальших досліджень. Після адаптації Міжнародної класифрікації фрункціонування, обмеження життєдіяльності та здоров'я для використання при обстеженні хворих із наслідками перенесеного інсульту необхідно продовжити дослідження есрективності первинної та вторинної профрілактики судинних захворювань головного мозку та формування індивідуальної програми реабілітації.

\section{Список літератури}

1. Волошин П. В. Профилактика мозгового инсульта / П. В. Волошин, Т. С. Мищенко // Здоров'я України. - 2002. № 5. - С. 14-17.

2. Зозуля І. С. Інсульт. Тактика, стратегія ведення, профілактика, реабілітація та прогнози (посібник для лікаряпрактика) / І. С. Зозуля, Ю. І. Головченко, О. П. Онопрієнко. - К. : Світ успіху, 2010. - 310 с.

3. Матяш М. М. Медико-експертні критерії обмеження життєдіяльності при зчМт / М. М. Матяш // Лікарська справа. - 2011. - № 7-8. - С. 98-106.

4. Международная классификация фрункционирования, ограничений жизнедеятельности и здоровья. - Женева : BO3, 2001. - 342 c.

5. Международная номенклатура нарушений, ограничений жизнедеятельности и социальной недостаточности : руководство по классификации болезней и причин инвалидности. - М., 1994. - 106 с.

6. Про затвердження Критеріїв встановлення ступеня стійкої втрати професійної працездатності у відсотках, особливостей працевлаштування хворих та інвалідів : наказ МО3 України від 05.08.1998 р. № 238 [Електронний ресурс]. - Режим доступу : www.zakon.rada.gov.ua/laws/show/z0652-98 
7. Про внесення змін до Інструкції про встановлення груп інвалідності : наказ МОЗ України від 23.11.2004 р. № 565 [Електронний ресурс]. - Режим доступу : https://законодавство.com/ukrajini-moz-nakaz/nakaz-23112004-565pro-vnesennya-zmin-2004-63197.html

8. Про затвердження Інструкції про встановлення груп інвалідності : наказ МОЗ України від 07.04.2004 р. № 183 [Електронний ресурс]. - Режим доступу : http://search.ligazakon.ua/l_doc2.nsf/link1/TM023784.html

9. Про затвердження та впровадження медико-технологічних документів зі стандартизації медичної допомоги при ішемічному інсульті : наказ МОЗ України від 03.08.2012 р. № 602 [Електронний ресурс]. - Режим доступу : http://old. moz.gov.ua/ua/portal/dn_20120803_602.html

10. Про затвердження та впровадження медико-технологічних документів зі стандартизації медичної допомоги при геморагічному інсульті : наказ МОЗ України від 17.04.2014 р. № 275 [Електронний ресурс]. - Режим доступу : httр:// old.moz.gov.ua/ua/portal/dn_20140417_0275.html

11. Олейник И. В. Состояние и перспективы решения мозковых инсультов, их социально-медицинских последствий (обзор литературы) / И. В. Олейник // Вісник морфології. - 2010. - Вип. 16 (3). - С. 734-737.

12. Онопрієнко О. П. Експертиза непрацездатності в невропатології, методологія фрормулювання діагнозу, профрілактика інвалідності, принципи реабілітації : посібник для лікаря-практика / О. П. Онопрієнко. - К. : ТОВ «Інпрес», 2015. - 668 с.

13. Основні принципи діагностики фрормування діагнозу, лікування та профілактики мозкового інсульту / I. С. Зозуля, Ю. І. Головченко, А. І. Зозуля [та ін.] // Укр. мед. часопис. - 2015. - № 5 (109). - С. 1-10.

14. Особенности эпидемиологии инвалидности при заболеваниях нервной системы в Украине: клинико-экспертные сопоставления / В. А. Голик, Н. А. Гондуленко, Е. Н. Мороз [и др.] // Український вісник медико-соціальної експертизи. 2013. - № 1. - С. 33-41.

15. Про реабілітацію інвалідів в Україні : Закон України від 06.10.2005 р. № 2961-IV // Відомості Верховної Ради України. - 2006. - № 2-3. - 36 с.

16. Рябова В. С. Отдалённые последствия мозгового инсульта / В. С. Рябова // Журнал неврология и психиатрия. 1986. - № 4. - С. 532-536.

17. Старовойтова И. М. Медицинская экспертиза: экспертиза временной нетрудоспособности, медико-социальная, военно-врачебная / И. М. Старовойтова, К. А. Саркисов, Н. П. Потехин. - М. : ГЭОТАР-Медиа, 2010. - 234 с.

18. Столярова Л. Г. Реабилитация больных с постинсультными двигательными расстройствами / Л. Г. Столярова, Г. Р. Ткачева. - М. : Медицина, 1978. - 216 с.

19. Gil Nunez A. C. Organization of medical care in acute stroke: importance network / A. C. Gil Nunez, J. Vivancos Mora // Cerebrovasc. Dis. - 2004. - Vol. 17 (Supp. 1) - P. 113-123.

\section{References}

1. Voloshin, P.V., \& Mishchenko, T.S. (2002). Profilaktika mozgovogo insulta [Prevention of cerebral stroke]. Zdorovia Ukrainy - Health of Ukraine, 5, 14-17 [in Russian].

2. Zozulia, I.S., Holovchenko, Yu.I., \& Onopriienko, O.P. (2010). Insult. Taktyka stratehiia vedennia, profilaktyka, reabilitatsiia ta prohnozy (posibnyk dlia likaria-praktyka) [Stroke. Tactics, strategy of management, prevention, rehabilitation and prognosis (manual for practitioner)]. Kyiv: Svit Uspikhu [in Ukrainian].

3. Matiash, M.M. (2011). Medyko-ekspertni kryterii obmezhennia zhyttiediialnosti pry ZChMT [Medico-expert criteria of limitation of vital activity at closeB craniocerebral injury]. Likarska sprava - Medical Case, 7-8, 98-106 [in Ukrainian].

4. (2001). Mezhdunarodnaya klassifikatsiya funktsionirovaniya, ogranicheniy zhiznedeyatelnosti i zdorovya [International classification of functioning, disability and health]. Zheneva: VOZ [in Russian].

5. (1994). Mezhdunarodnaya nomenklatura narusheniy, ogranicheniy zhiznedeyatelnosti $i$ sotsialnoy nedostatochnosti: Rukovodstvo po klassifikatsii bolezney i prichin invalidnosti [International nomenclature of violations, disability and social insufficiency: A guide to the classification of diseases and causes of disability]. Moscow [in Russian].

6. Nakaz MOZ Ukrainy № 238 vid 05.08.1998. "Pro zatverdzhennia Kryteriiv vstanovlennia stupenia stiikoi vtraty profesiinoi pratsezdatnosti u vidsotkakh, osoblyvostei pratsevlashtuvannia khvorykh ta invalidiv" [Order of the Ministry of Health of Ukraine No. 238 of 05.08.1998. "On Approval of the Criteria for Establishing the Degree of Sustainable Loss of Professional Disability in Percentages, Peculiarities of the Employment of Patients and Disabled Persons"]. - Retrieved from: www. zakon.rada.gov.ua/laws/show/z0652-98 [in Ukrainian].

7. Nakaz MOZ Ukrainy № 565 vid 23.11.2004 r. "Pro vnesennia zmin do Instruktsii pro vstanovlennia hrup invalidnosti" [The Order of the Ministry of Health of Ukraine No. 565 dated November 23, 2004 "On Amendments to the Instruction on the Establishment of Disabled Groups"]. - Retrieved from: https://zakonodavstvo.com/ukrajini-moz-nakaz/nakaz-23112004565-pro-vnesennya-zmin-2004-63197.html [in Ukrainian].

8. Nakaz MOZ Ukrainy № 183 vid 07.04.2004 r. "Pro zatverdzhennia Instruktsii pro vstanovlennia hrup invalidnosti" [Order of the Ministry of Health of Ukraine No. 183 of 07.04.2004 "On Approval of the Instruction on the Establishment of Disabled Groups"]. - Retrieved from: http://search.ligazakon.ua/l_doc2.nsf/link1/TM023784.html [in Ukrainian].

9. Nakaz MOZ Ukrainy № 602 vid 03.08.2012 "Pro zatverdzhennia ta vprovadzhennia medyko-tekhnolohichnykh dokumentiv zi standartyzatsii medychnoi dopomohy pry ishemichnomu insulti" [Order of the Ministry of Health of Ukraine No. 602 of August 3, 2012 "On Approval and Implementation of Medical-Technological Documents for the Standardization of Medical Assistance in Ischemic Stroke"]. - Retrieved from: http://old.moz.gov.ua/ua/portal/dn_20120803_602.html [in Ukrainian].

10. Nakaz MOZ Ukrainy № 275 vid 17.04.14 "Pro zatverdzhennia ta vprovadzhennia medyko-tekhnolohichnykh dokumentiv zi standartyzatsii medychnoi dopomohy pry hemorahichnomu insulti" [Order of the Ministry of Health of Ukraine No. 275 
dated 17.04.14 "On Approval and Implementation of Medical-Technological Documents on Standardization of Medical Aid in a Hemorrhagic Stroke"]. - Retrieved from: http://old.moz.gov.ua/ua/portal/dn_20140417_0275.html [in Ukrainian].

11. Oleynik, I.V. (2010). Sostoyaniye i perspektivy resheniya mozkovykh insultov, ikh sotsialno-meditsinskikh posledstviy (obzor literatury) [The state and prospects of the decision of cerebral strokes, their social and medical consequences (literature review)]. Vísnyk morfolohii - News of Morphology, 16 (3), 734-737 [in Russian].

12. Onopriienko, O.P. (2015). Ekspertyza nepratsezdatnosti $v$ nevropatolohii metodolohiia formuliuvannia diahnozu, profilaktyka invalidnosti, pryntsypy reabilitatsii: Posibnyk dlia likaria-praktyka [Expertise of disability in neuropathology methodology of formulation of a diagnosis, prevention of disability, principles of rehabilitation: A manual for a doctorpractitioner]. Kyiv: TOV "Inpres" [in Ukrainian].

13. Zozulia, I.S., Holovchenko, Yu.I., Zozulia, A.I., Onopriienko, O.P., \& Volosovets, A.O. (2015). Osnovi pryntsypy diahnostyky formuvannia diahnozu, likuvannia ta profilaktyky mozkovoho insultu [Principles of diagnosis, treatment and prevention of brain stroke]. Ukr. med. Chasopys - Ukrainian Medical Journal, 5 (109) IX/X, 1-10 [in Ukrainian].

14. Golik, V.A., Gondulenko, N.A., Moroz, E.N., \& Boguslavskyy, D.D. (2013). Osobennosti epidemiologii invalidnosti pri zabolevaniyakh nervnoy sistemy $v$ Ukraine: kliniko-ekspertnyye sopostavleniya [Features of the epidemiology of disability in diseases of the nervous system in Ukraine: clinical and expert comparisons]. Ukrainskyi visnyk medyko-sotsialnoi ekspertyzy - Ukrainian Bulletin of Medical and Social Expertise, 1, 33-41 [in Ukrainian].

15. Pro reabilitatsiiu invalidiv v Ukraini: Zakon Ukrainy № 2961-IV vid 06.10.2005 r. [On Rehabilitation of Disabled Persons in Ukraine: Law of Ukraine No. 2961-IV of 06.10.2005]. (2006). Vidomosti Verkhovnoi Rady Ukrainy - Bulletin of the Verkhovna Rada of Ukraine, 2-3, 36 [in Ukrainian].

16. Ryabova, V.S. (1986). Otdalennyye posledstviya mozgovogo insulta [Long-term consequences of cerebral stroke]. Zhurnal nevrologiya i psikhiatriya - Journal of Neurology and Psychiatry, 4, 532-536 [in Russian].

17. Starovoytova, I.M., Sarkisov, K.A., \& Potekhin, N.P. (2010). Meditsinskaya ekspertiza: ekspertiza vremennoy netrudosposobnosti, mediko-sotsialnaya, voyenno-vrachebnaya [Medical examination: examination of temporary incapacity for work, medical-social, military-medical]. Moscow: GEOTARMedia [in Russian].

18. Stolyarova, L.G., \& Tkachev, G.R. (1978). Reabilitatsiya bolnykh s postinsultnymi dvigatelnymi rasstroystvami [Rehabilitation of patients with poststroke motor disorders]. Moscow: Meditsina [in Russian].

19. Gil Nunez, A.C., \& Vivancos Mora, J. (2004). Organization of medical care in acute stroke: importance network. Cerebrovasc. Dis., 17 (1), 113-123.

\section{МЕДИКО-ЭКСПЕРТНЫЕ КРИТЕРИИ ОГРАНИЧЕНИЯ ЖИЗНЕДЕЯТЕЛЬНОСТИ ПРИ ПОСЛЕДСТВИЯХ ПЕРЕНЕСЕННОГО ИНСУЛЬТА}

М.Н. Матяш' ${ }^{1}$ А.П. Оноприенко ${ }^{2}$

${ }^{1}$ Киевский международный медицинский университет, г. Киев, Украина

Броварская центральная районная больница, г. Бровары, Украина

Цель: адаптировать Международную классификацию функционирования, ограничения жизнедеятельности и здоровья (МКФ) для использования при обследовании больных с последствиями перенесенного инсульта.

Материалы и методы. В ангионеврологическом отделении Броварской центральной больницы проведено исследование 110 больных трудоспособного возраста с последствиями перенесенного инсульта. Все больные прошли стандартное клиническое неврологическое обследование и тестирование по МКФ.

Результаты. Определены фракторы, разработаны критерии ограничения жизнедеятельности в главных сорерах жизни. Доказано, что адаптация МКФ позволяет применять ее при экспертной диагностике, фрормулировке правильного клинического, функционального диагноза, дает возможность оценить потенциал и эфрфективность реабилитационных мероприятий у больных с последствиями перенесенного инсульта.

Выводы. 1. Применение МКФ дает возможность объективно оценить состояние больных, реабилитационный потенциал и эфрфективность проведения реабилитационных мероприятий у больных с последствиями перенесенного инсульта.

2. Использование разработанных нами критериев ограничения жизнедеятельности позволит повысить качество медико-социальной экспертизы больных, перенесших инсульт, а дальнейшие исследования оптимизировать новые подходы к реабилитации этой категории больных и адаптации в обществе.

КЛЮЧЕВЫЕ СЛОВА: последствия перенесенного инсульта; диагноз; медико-социальная экспертиза; ограничение жизнедеятельности; Международная классификация функционирования.

\section{MEDICAL ASSESSMENT CRITERIA OF LIMITATION OF VITAL FUNCTIONS AT THE CONSEQUENCES OF STROKE}

M.M. Matyash, O.P. Onopriyenko

Kyiv International Medical University, Kyiv, Ukraine

Brovary Central District Hospital, Brovary, Ukraine

Purpose: to adapt "International classification of functioning, limitation of vital functions and health" (ICFH) focusing for the inspection of patients with the consequences of the prior stroke. 
Materials and Methods. In the angyoneurology separation of the Brovary Central Hospital a study is undertaken 110 patients with the consequences of stroke, capable of working age. All patients passed a standard clinical neurological inspectionand testing after ICFH.

Results. Factors are certain, the criteria of limitation of vital functions are worked out in the main spheres of life. It is well-proven that adaptation of ICFH allows to apply it at expert diagnostics, to formulation of correct clinical,functional diagnosis, gives an opportunity to estimate potential and efficiency of rehabilitation measures for patients with the consequences of the prior stroke.

Conclusions. 1. Application of ICFH gives an opportunity actively to estimate the state of patients, rehabilitation potential and efficiency of realization of rehabilitation measures for patients with the consequences of the prior stroke.

2. The use of the criteria of limitation of vital functions worked out by us will allow to improve quality medicosocial examination of patients that suffered a stroke, and to optimize further researches new going near the rehabilitation of this category of patients and adaptation in society.

KEY WORDS: the consequences of stroke; medico-social examination; limitation of vital functions; international classification of functioning.

Рукопис надійшов до редакції 22.01.2018 р.

Відомості про авторів:

Матяш Михайло Миколайович - доктор медичних наук, професор, ректор Київського міжнародного медичного університету; тел.: +38(050) 353-05-53; +38(098) 103-37-50.

Онопрієнко Олексій Павлович - кандидат медичних наук, завідувач ангіоневрологічного відділення Броварської центральної районної лікарні; тел.: +38(097) 067-55-74. 